\title{
Effect of administration of leptin on thyroid hormone in oxidative stress induced rats
}

Received : 7/12/2017

Accepted : 18/1/2018

\author{
Shaymaa Rabeea Madhkhoor1, Ihsan Raisan Ibrahim2 . \\ 1. College of Biotechnology, University of Al-Qadisiyah, Iraq. \\ 2. College Of Pharmacy, University of Al-Qadisiyah, Iraq \\ e.mail:shaymaa.rebeaa@qu.edu.iq
}

\begin{abstract}
The aim of this study was to investigate the relationship between exogenous leptin and thyroxin on some stress types in rats. In this study 60 male wistar albino rats were divided into two main groups (first was 5 day, and second was 10 day), each one subdivided into six groups (5 rat per subgroup): Control And five treated groups, which include: Leptin $(10 \mu \mathrm{g} / \mathrm{kg}$ leptin, sc. daily), oxidative stress $\left(0.5 \% \mathrm{H}_{2} \mathrm{O}_{2}\right)$, leptin+ oxidative stress, Diabetes, (induced by single injection of streptoztocin (65 $\mathrm{mg} / \mathrm{kg} \mathrm{bw})$ ), and Leptin + diabetes. At the end of the experiments the blood collected by cardiac puncture under anesthesia. Plasma thyroxin and corticosterone were measured. Our results showed that stress decreases thyroxin level and increases corticosterone level, while leptin treatment reverse these changes.
\end{abstract}

Key words: leptin, thyroid, T4, oxidative stress.

\section{Introduction}

Leptin is a 146 -amino acid polypeptide which is produced by adipocytes [1]. The receptor of this hormone is located in different parts of the body, not only regulates lipid and energy homeostasis, but it also affects neuroendocrine and immune function [2]. Leptin is regulated by a problematical complex consisted of several mediators, including insulin, Glucocorticoids and thyroid hormones [3].

Thyroid hormones include triiodothyronine (T3) and thyroxine (T4) are tyrosine-based hormones produced by the thyroid gland that are primarily responsible for regulation of metabolism. Thyroid-stimulating hormone (also known as TSH or thyrotropin) is a hormone that stimulates the thyroid gland to produce $\mathrm{T} 4$ and $\mathrm{T} 3$, then $\mathrm{t} 4 \mathrm{c}$ cnverted to $\mathrm{t} 3$ which stimulates the metabolism of almost every tissue in the body [4]. Thyroid hormones as well as leptin are involved in regulation of energy metabolism, thermogenesis, food intake, glucose and lipid metabolism as well as oxidation of fatty acids [5]. There are some studies on the contribution of leptin to the modulation of thyroidstimulating hormone (TSH) secretion in rodents. It has been demonstrated that leptin stimulates TSH secretion in rats [6]. However, according to [7] in vitro leptin inhibits release of thyroid-stimulating hormone from male rats pituitary cells, while it has a stimulatory effect on the 
TSH secretion in vivo.

Stress induces changes in the secretion of several hormones, which affect immune function by either increasing or decreasing immune activity. The thyroid hormones are essential for the maintenance of neurotransmitters associated with stress, and have also a significant impact on the immune

response

[8].

Different types of stress influence on many functions of body such as endocrine

\section{Material and Methods}

The present study has been conducted at the animal house of education college of university of AL-Qadisiyah , 60 male Wistar albino rats weighing $200 \pm 20 \mathrm{~g}$ were used in this study. They were fed a standard laboratory diet and drinking water ad libitum and kept in a room with controlled temperature ( $22 \pm 1$ o C), and a 12:12-h light-dark cycle. They were divided into two main groups (first was 5 day, and second was 10 day), each one subdivided into six groups (5 rat per subgroup).

Control group : daily received physiological saline for (5\& 10) day. and rats of five treated groups (leptin groups ; $10 \mu \mathrm{g} / \mathrm{kg}$, recombinant human leptin, sc. daily. Oxidative stress group; $0.5 \% \mathrm{H}_{2} \mathrm{O}_{2}$ gives daily and ad libitum in water. Leptin + oxidative stress. Diabetes group, a single ip injection of STZ at a dose of 65

\section{Results}

Corticosterone levels: Plasma corticosterone levels, are shown in table 1 , were non significantly higher in the system and immune system [9]. In fact, many hormonal changes can be occurred during stress [10].

Occasionally the endocrine disorders, such as thryroid abnormalities are associated with Diabetes [11]. Since, thyroid hormones are involved in cellular metabolism, excess or deficit of these hormones can result in functional derangement of cell [12]. The aim of this study was to investigate the relationship between exogenous leptin and thyroxin on some stress types in rats

$\mathrm{mg} / \mathrm{kg}$ bw, and Leptin + diabetes group; leptin injections $10 \mu \mathrm{g} / \mathrm{kg}$ sc. daily).

Diabetes was induced in overnight fasted rats by a single intraperitoneal injection of STZ (SIGMA Chemicals, USA) at adose of $65 \mathrm{mg} / \mathrm{kg}$ body weight freshly dissolved in $0.1 \mathrm{~mol} / \mathrm{L}$ citrate buffer, $\mathrm{pH} 4.5$.The animals with fasting blood glucose values more than $250 \mathrm{mg} / \mathrm{dl}$ after $72 \mathrm{~h}$ of STZ injection were considered diabetic and included in the study one week after induction of diabetes [13], rats began treatment protocol of leptin injections. Blood sample of each rats from each groups at the end of experiment were obtained for studying by heart puncher.

Serum Biochemical parameters: In serum, thyroxin and corticosterone levels were measured by enzyme immunoassay (ELISA) kit (ABO, Switzerland).

leptin groups than the control groups in 5 and 10 groups. Plasma corticosterone levels were significantly $(\mathrm{p}<0.05)$ increase 
in the oxidative stress and diabetes groups than the control groups. Leptin administration $(10 \mu \mathrm{g} / \mathrm{kg}$ s.c. for 5 and 10 days) to leptin+ (oxidative stress \& diabetes) groups led to decrease in plasma corticosterone as compared to the control, oxidative stress and diabetes groups. A similar result was obtained between the 5 and 10 days experiments, and the difference were statistically $(\mathrm{p}<0.05)$ significant in all groups.

Table 1: Corticosterone levels in the plasma of control, leptin, oxidative stress, leptin+oxidative stress, diabetes, and leptin+diabetes groups.

\begin{tabular}{|c|rr|rl|}
\hline \multirow{2}{*}{ Groups } & \multicolumn{4}{|c|}{ Corticosterone level $(\mathrm{pg} / \mathrm{ml})$} \\
\cline { 2 - 5 } & \multicolumn{5}{|c|}{ Day } & $\mathbf{1 0}$ Day & \\
\hline Control & $39.20 \pm 1.34$ & a & $39.00 \pm 1.41$ & e \\
\hline Leptin & $* 39.60 \pm 1.18$ & a & $44.00 \pm 1.09$ & e \\
\hline Oxidative stress & $* 150.00 \pm 2.11$ & b & $110.20 \pm 2.01$ & c \\
\hline Oxidative stress+leptin & $* 70.60 \pm 1.21$ & ca & $77.40 \pm 0.42$ & a \\
\hline Diabetes & $* 178.40 \pm 3.14$ & b & $126.60 \pm 0.41$ & c \\
\hline Diabetes + leptin & $* 81.20 \pm 1.41$ & c & $\mathbf{1 0 0 . 8 0} \pm 30.11$ & ca \\
\hline LSD & 35.11 & & $\mathbf{2 6 . 5 5}$ & \\
\hline
\end{tabular}

Each value represents the mean \pm S.D. of five animals per group. Star $(*)$ represents significant difference between ( 5 and 10 day) groups. The different letters indicate that there is a significant difference $(\mathrm{p}<0.05)$ between the different groups within the period of time.

Thyroxin levels: Plasma Thyroxin levels are shown in table 2, Plasma Thyroxin levels were significantly $(\mathrm{p}<0.05)$ higher in the leptin groups than the control groups in 5 and 10 groups. Plasma Thyroxin levels were (non significantly in 5 day group, and significantly $(\mathrm{p}<0.05)$ in 10 day group) lower in the oxidative stress and diabetes groups than the control groups. Leptin administration $(10 \mu \mathrm{g} / \mathrm{kg}$ s.c. for 5 and 10 days) for each groups leptin + oxidative stress and leptin + diabetes groups led to significantly $(\mathrm{p}<0.05)$ increase in plasma Thyroxin levels compared to the oxidative stress and diabetes groups, and control groups at 10 days . A similar result was obtained between the 5 and 10 days experiments, and the difference were statistically significant $(\mathrm{p}<0.05)$ in leptin, Oxidative stress+leptin and diabetes+leptin groups.

Table 2: Thyroxin levels in the plasma of control, leptin, oxidative stress, leptin+oxidative stress, diabetes, and leptin+diabetes groups.

\begin{tabular}{|c|c|c|c|}
\hline \multirow[t]{2}{*}{ Groups } & \multicolumn{3}{|c|}{ Thyroxin level $(\mu \mathrm{g} / \mathrm{L})$} \\
\hline & 5 Day & 10 Day & \\
\hline Control & $* 45.20 \pm 2.09$ bc & $52.8 \pm 0.74$ & b \\
\hline Leptin & $* 61.80 \pm 1.04 a$ & $65.8 \pm 0.42$ & $\mathbf{a}$ \\
\hline Oxidative stress & $35.20 \pm 1.31$ c & $37.4 \pm 1.18$ & $\mathbf{c}$ \\
\hline Oxidative stress+leptin & $* 54.80 \pm 1.42 \quad \mathrm{ab}$ & $67.20 \pm 1.62$ & $\mathbf{a}$ \\
\hline
\end{tabular}




\begin{tabular}{|c|r|r|r|}
\hline Diabetes & $\mathbf{3 8 . 0 0} \pm 1.17$ c & $\mathbf{3 3 . 0 0} \pm 0.86$ & c \\
\hline Diabetes + leptin & $* \mathbf{5 3 . 4 0 \pm 0 . 8 9}$ ab & $\mathbf{6 0 . 8} \pm 0.81$ & a \\
\hline LSD & 14.05 & 6.47 & \\
\hline
\end{tabular}

Each value represents the mean \pm S.D. of five animals per group. Star (*) represents significant difference between ( 5 and 10 day) groups. The different letters indicate that there is a significant difference $(p<0.05)$ between the different groups within the period of time.

\section{Discussion}

In the present study oxidative stress and diabetes mellitus causes increase in corticosterone level, this finding agreement with [14].

As stress activates the hypothalamicpituitary-adrenal(HPA) axis, which leads to an increase in corticosterone leve in rodents and cortisol in humans, an indication of the existence of stress and severity [15]. The high level of corticosterone after exposure for many types of effects has become known, but the precise mechanism of this rise remains unclear, but may be related to change the effectiveness of the (HPA) axis in response to stress, resulting in changes in the secretion of Corticotropine Releasing Hormone (CRH) and Adrenocorticotropic Hormone (ACTH) and genetic expression of Proopiomelanocortin (POMC), appears to increase the secretion of glucocorticoids during Stress is important, as an appropriate defense mechanism[16]

The cases of stress caused a significant decrease in the level of thyroxin in the second period and was not significant in the first period. The results of this study agree with [11] and [17].

[18] reported that low thyroid activity is associated with increased oxidative stress and lack of antioxidants, so, the formation of reactive oxygen species is increased, mitochondria are affected, energy production is reduced and cellular components are affected, which negatively affects the level of thyroid hormones.

Groups of animals exposed to stress and treatment with leptin showed a significant increase in thyroxine levels compared with groups of animals exposed to stress conditions only and compared to control groups. These results are consistent with many previous studies [7] [19] [20] [21]

Leptin directly affects on the regulation of the thyroid axis by regulating the formation and secretion of Thyrotropin Releasing Hormone (TRH) by direct insertion of the arcuate nucleus into the TRH neurons in the paraventricular nucleus [22].

In addition, the thyroid axis is indirectly regulated by leptin through its effect on the melanocortin pathway, as melanocyte stimulating hormone stimulates TRH release and inhibits its release by Agouti related peptide [23] increases the direct effects of leptin on TRH neurons and regulates their structure not only by regulating the gene expression of the proTRH gene in the paraventricular nucleus [24] and its effect on the regulation of feedback of TRH neurones by thyroid hormones but also by increasing the activity of turning TRH from pro-TRH [25]. 
[26] indicated that giving the subcutaneous leptin to healthy rats for 6 days stimulates the growth and secretion of thyroid gland through a direct mechanism involving the presence of leptin receptors on the thyroid, leading to an increase in thyroxine levels, This is also found in the present study.

\section{References}

1. Ide, S. Tokuyama R, Davaadorj P, Shimozuma M, Kumasaka S, Tatehara S, et al.(2011). Leptin and vascular endothelial growth factor regulate angiogenesis in tooth germs. Histochem Cell Bio. 135(3):281- 92.

2. Ziylan YZ, Baltaci AK, Mogulkoc R.(2009). Leptin transport in the central nervous system. Cell Biochem Funct. 27(2): 63-70.

3. Gainsford $\mathrm{T}$, Alexander WS.(1999). A role for leptin in hemopoieses?

Mol

Biotechnol.11(2): 149-58.

4. Ghadiri, E.; Ahmadi, R. and Nargesi. A.(2014).Effects of Darkness Stress on Thyroid Function. International Conference on Chemical, $J$. Agricul. and Med. Sci.,10:39-40.

5. Huynh FK, Neumann UH, Wang Y, Rodrigues B, Kieffer TJ, Covey SD.(2013). A role for hepatic leptin signaling in lipid metabolism via altered very low density lipoprotein composition and liver lipase activity in mice. Hepatology.57: 543-554.

6. Casanueva FF, Dieguez C. (1999).Neuroendocrine regulation and actions of leptin. Front Neuroendocrinol.20: 317-363.

7. Ortiga-Carvalho, T.M.; Oliveira, K.J.; Soares, B.A. and PazosMoura, C.C.(2002). The role of leptin in the regulation of TSH secretion in the fed state: in vivo and in vitro studies. J. Endocrin., 174:121-125.
[27] reported that chronic stress can reduce the levels of thyroid hormone in mice. This is reflected in the current study results from the lower level of hormone in the second period compared to the first period in animals exposed to metabolic stress

(diabetes).
8. Kav Vedhara, Jeremy Miles, Paul Bennett, Sue Plummer, Deborah Tallon, Emily Brooks, Lone Gale, Katherine Munnoch, Christa SchreiberKounine, Clare Fowler, Stafford Lightman, Alistair Sammon, Zenon Rayter, John Farndon. (2003). An investigation into the relationship between salivary cortisol, stress, anxiety and depression. Biological Psychology. 62 89-96.

9. Segerstrom S, E.Miller G. (2004).Psychological Stress and the Human Immune System: A Meta-Analytic Study of 30 Years of Inquiry. Psychol Bull. July; 130(4): 601-630.

10. Ranabir S, Reetu K. (2011).Stress and hormones. Indian $\mathrm{J}$ Endocrinol Metab. Jan-Mar; 15(1): 18-22.

11. Hage, M.; Mira, S.; Zantout, G. and Sami, T. (2011). Thyroid Disorders and Diabetes Mellitus. J. Thyroid Res.,1:7.

12. Singh G, Gupta V, Sharma AK et al. Evaluation of thyroid dysfunction among type 2 diabetic Punjabi population. Adv biores (2011); 2: 3-

13. Akbarzadeh, A.; Norouzian, D.; Mehrabi, M. R.; Jamshidi, S. and Lame, R.(2007). Induction of diabetes by Streptozotocin in rats. Indian. J. Clin. Biochem.,22(2): 60-64.

14. Torres, R.C.; Prevatto, J.P.; Silva, P.; Martinsand, M.A. and Carvalho, V.F.(2013). From Type- 
1 Diabetes HPA Axis to the Disease Complications. J. Diab. Metab.,12:2.

15. Sheikh, N.; Ahmad, A.; Siripurapu, K.B.; Kuchibhotla, V.K.; Singh, S. and Palit, G.(2007). Effect of Bacopa monniera on stress-induced changes in plasma corticosterone and brain monoamines in rats. $J$. Ethnopharmacol.,111: 671-676.

16. Chandralekha, G.; Jeganathan, R.; Viswanathan, B. and Charan, J.C.(2005). Serum leptin and corticosterone levels after exposure to noise stress in rats. Malaysian J. Med. Sci.,12(1):5156.

17. Mohamed, A. E.; Abdel-Aziz, A. F.; El-Sherbiny, E.M. and Morsi, R.M. (2009). Anti-diabetic effect of aloe vera juice and evaluation of thyroid function in female diabetic rats. J. Biosci. Res.,6(1): 28-34.

18. BhawnaBhimte, B.K.; Agrawal, V.K.; Sharma and Sarika Singh C. (2012). Oxidative stress status in hypothyroid patients.J.Biomed. Res. 23(2): 286-288.

19. Cusin, I.; Rouru, J.; Visser, T.; Burger, A.G. and RohnerJeanrenaud, F.(2000). Involvement of Thyroid Hormones in the Effect of Intracerebroventricular Leptin Infusion on Uncoupling Protein-3 Expression in Rat Muscle. $J$. Diabetes, 49:1101-1105.

20. Seoane, L.M.; Carro, E.; Tovar, S.; Casanueva, F.F. and Dieguez, C.(2000). Regulation of in vivo TSH secretion by leptin. $J$. Regulatory Peptides, 92:25-29.

21. Sone, M. and Osamura, R.Y.(2001). Leptin and pituitary. J. Pituitary., 4:15-23.

22. Paz-Filho, G.; Delibasi, T.; Erol, H.K.; Wong, M. and Licinio, J.(2009). Congenital leptin deficiency and thyroid function. J.Thyroid Res., 2:11.
23. Kim, M.S.; Small, C.J.; Stanley, S.A.; Morgan, D.G.; Seal, L.J.; Kong, W.M. ; Edwards, C.M.; Abusnana, S. ; Sunter, D. ; Ghatei, M.A. and Bloom, S.R.(2000). The central melanocortin system affects the hypothalamo-pituitary thyroid axis and may mediate the effect of leptin. J. Clin. Invest.,105:1005-1011.

24. Nillni, E.A.; Vaslet, C. ; Harris, M. ; Hollenberg, A. ; Bjorbak, C. and Flier, J.S.(2000). Leptin regulates prothyrotropin-releasing hormone biosynthesis. Evidence for direct and indirect pathways. $J$. Biol. Chem.,275:36124-36133.

25. Nillni, E.A.(2007). Regulation of prohormone convertases in hypothalamic neurons: implications for prothyrotropinreleasing hormone and proopiomelanocortin. Endocrin., 148:4191-4200.

26. Nowak, K.W.; Kaczmarek, P.; Mackowiak, P.; Ziolkowska, A.; Albertin, G.; Ginda, W.J.; Trejter, M.; Nussdorfer, G.G. and Malendowicz, L.K.(2002). Rat thyroid gland expresses the long form of leptin receptors, and leptin stimulates the function of the gland in euthyroid non-fasted animals. Int. J. Mol. Med. 9:3134.

27. Silberman, D.M.; Wald, M. and Genaro, A. M. (2002). Effects of chronic mild stress on lymphocyte proliferative response. Participation of plasma thyroid hormones and corticosterone. $J$. Int. Immunopharmacol. 2: 487497. 